\title{
STUDIES ON THE INTERRELATIONSHIP BETWEEN YIELD AND AGRONOMIC TRAITS IN SOME SELECTED SOYBEAN LINES AT YANDEV IN SOUTHERN GUINEA SAVANNAH OF NIGERIA
}

\author{
Gabriel Ojonimi ABIMAJE ${ }^{1}$, Terkimbi $\mathrm{VANGE}^{2}$, David Kparafa ADEDZWA², \\ $\underline{\text { Aondover SHAAHU }}^{3 *}$ \\ ${ }^{1}$ Department of Agriculture, Yagba East Local Government Council, Kogi State - Nigeria \\ ${ }^{2}$ Federal University of Agriculture, Makurdi, Benue State - Nigeria \\ ${ }^{3}$ National Cereals Research Institute, Badeggi, Niger State - Nigeria \\ ${ }^{*}$ Corresponding author. E-mail: iorpen001@ gmail.com
}

\begin{abstract}
A field trial was conducted during the 2010 cropping season at the experimental farm of Akperan Orshi College of Agriculture, Yandev-Gboko, Benue State. The plots were laid in Randomized Complete Block Design with three replications. The analysis of variance showed significant in difference in nodule dry weight; days to $50 \%$ flowering; days to maturity; plant height at maturity; number of branches; number of pods per plant; number of seeds/ plant; and weight of 100 seeds among the genotypes studied. The result of this experiment conducted showed that there were highly significant correlation on number of pods per plant, number of seeds per plant, and significant correlation of one hundred seed with seed yield. The results of the path coefficient analysis also showed that number of pods per plant exerted the highest direct effect on seed yield. Weight $(\mathrm{g})$ of one hundred seeds showed the least direct effect among the traits evaluated. The regression on seed yield and its component character also showed that number of pods per plant had the highest contribution to seed yield with the proportion due to regression being $48 \%$. The relative contribution of number of branches per plant to seed yield was $2 \%$.
\end{abstract}

Keywords: Correlation, genotypes, path analysis, regression, soybean.

\section{Introduction}

Soybean (Glycine max (L.) Merrill) is a legume that grows in tropical, subtropical, and temperate climates. Soybean is not an indigenous crop in Nigeria, although, it is gaining popularity in the country because of its numerous potentials that rank it even better than cowpea in the supply of high quality protein [AKANDE \& al. 2007]. Soybean grains contain about $40 \%$ protein, $20 \%$ oil, an optimal supply of essential amino acids and nutrients, and a high calorie value [SINGH \& al. 2008]. The main goal of growing crops is to maximize net profit through increasing grain yield [ALGHAMDI, 2004]. Hence, the primary goal of most soybean breeding programs is high grain yield [TOLEDO \& al. 2000]. According to GRAFIUS (1959) increasing total yield would be made easier by selecting for the yield components because the yield components are more simply inherited than the total yield itself. Thus, studies on correlation enable the breeder to know the mutual relationship between various characters and determine the yield components to select, to improve the yield of the crop. Seed yield, as complex trait, is the result of the expression of the association of several plant growth components. So, selection for seed yield should take into account related characters. Hence, the knowledge of correlation between yield and yield components and among the components themselves is essential for yield improvement through selection programs. The objectives of this study was to determine 
the genetic variability that exist among the selected genotypes; to estimate the correlation coefficients between the seed yield of soybean and its components; and to identify traits that influenced yield of soybean and select them in order to improve its' yield.

\section{Material and methods}

The experimental material for the present study comprised of twenty(20) elite soybean genotypes. The sources and characteristics of these soybean genotypes used are presented in Table 1. A field trial was conducted during the 2010 cropping season at the experimental farm of the Akperan Orshi College of Agriculture, Yandev-Gboko, Benue State. Soil samples were taken from experimental site for analysis to determine the physical and chemical properties at the NICANSOL soil testing laboratory of the University of Agriculture, Makurdi. The textural class and the chemical properties of the soil are presented in Table 2a \& Table 2b. The site is $117 \mathrm{~m}$ above sea level (a.s.l.m.) as altitude, $07^{\circ} 22^{\circ} \mathrm{N}$ and $08^{\circ} 37^{\circ} \mathrm{E}$ as longitude and latitude respectively.

Table 1. Soybean Genotypes, Sources and Characteristics.

\begin{tabular}{|c|c|c|c|}
\hline $\mathbf{S} / \mathbf{N}$ & Genotype Code & Sources & Variety's Characteristics \\
\hline 1 & NCRI SOY 16 & NCRI, Badeggi & Medium maturing, resistant to shattering \\
\hline 2 & NCRI SOY 5 & NCRI,Badeggi & Medium maturing, resistant to shattering \\
\hline 3 & SAMSOY 2 & UAM & Medium maturing, susceptible to shattering \\
\hline 4 & TGX $1440-1 \mathrm{E}$ & IITA, IBADAN & Medium maturing, resistant to shattering \\
\hline 5 & TGX $1448-2 \mathrm{E}$ & IITA, IBADAN & Medium maturing, resistant to shattering \\
\hline 6 & TGX $1485-1 \mathrm{D}$ & IITA, IBADAN & Early maturing, low shattering \\
\hline 7 & TGX $1835-10 \mathrm{E}$ & IITA, IBADAN & Early maturing, low shattering \\
\hline 8 & TGX $1904-6 F$ & IITA, IBADAN & Medium maturing, resistant to shattering \\
\hline 9 & TGX $1984-17 F$ & IITA, IBADAN & Late maturing \\
\hline 10 & TGX 1984 19F & IITA, IBADAN & Late maturing \\
\hline 11 & TGX $1984-1 \mathrm{~F}$ & IITA, IBADAN & Late maturing \\
\hline 12 & TGX $1984-22 F$ & IITA, IBADAN & Late maturing \\
\hline 13 & TGX $1984-5 F$ & IITA, IBADAN & Medium maturing \\
\hline 14 & TGX $1985-12 F$ & IITA, IBADAN & Medium maturing \\
\hline 15 & TGX $1986-1 \mathrm{~F}$ & IITA, IBADAN & Medium maturing. \\
\hline 16 & TGX $1987-10 \mathrm{~F}$ & IITA, IBADAN & Extra early maturing, resistant to shattering \\
\hline 17 & TGX $1987-19 F$ & IITA, IBADAN & Late maturing \\
\hline 18 & TGX $1987-57 \mathrm{~F}$ & IITA, IBADAN & Medium maturing \\
\hline 19 & TGX 1987- 62F & IITA, IBADAN & Extra early maturing, resistant to rust \\
\hline 20 & TGX $923-2 \mathrm{E}$ & IITA, IBADAN & Late maturing \\
\hline
\end{tabular}

Abbreviations: NCRI = National Cereals Research Institute, UAM = University of Agriculture, Makurdi, IITA = International Institute for Tropical Agriculture, Ibadan.

Tab. 2a. Physical properties of the Yandev-Gboko, Benue State.

\begin{tabular}{lcc}
\hline Soil Parameters & \multicolumn{2}{c}{ Yandev-Gboko, Benue State } \\
\hline & Sand & 80.0 \\
Particle Size Distribution (\%) & Silt & 15.9 \\
& Clay & 4.1 \\
\hline \multirow{2}{*}{ Textural Class } & & Loamy \\
& & Sand \\
$\mathrm{pH}$ & 6.15 & \\
$\mathrm{H}_{2} \mathrm{O}$ & $1: 1$ & \\
\hline
\end{tabular}


ABIMAJE GABRIEL OJONIMI \& al.

Tab. 2b. Chemical properties of the soil at Yandev-Gboko, Benue State.

\begin{tabular}{lcc}
\hline \multicolumn{3}{c}{ Yandev-Gboko, Benue State } \\
\hline \multirow{2}{*}{ Organic $(\%)$} & $\mathrm{C}$ & 0.63 \\
& $\mathrm{M}$ & 1.09 \\
& $\mathrm{~N}$ & 0.088 \\
\hline Available & $\mathrm{P}(\mathrm{ppm})$ & 2.79 \\
\hline & $\left(\mathrm{Cmol} \mathrm{kg}^{-1}\right)$ & \\
Exchangeable bases & $\mathrm{Ca}$ & 2.41 \\
& $\mathrm{Mg}$ & 1.92 \\
& $\mathrm{~K}$ & 0.76 \\
& $\mathrm{Na}$ & 0.48 \\
\hline Abbreviations: $\mathrm{C}=$ carbon, $\mathrm{M}=$ magnesium, $\mathrm{N}=$ nitrogen, $\mathrm{CEC}=$ cation exchange capacity
\end{tabular}

The experimental site was cleared, ploughed, harrowed, and ridged in mid-June to mid-July of the year 2010. Plots were laid in a Randomized Complete Block Design (RCBD) with three replications. Plot size was $5 \mathrm{mx} 1.5 \mathrm{~m}$, giving a plot area of $7.5 \mathrm{~m}^{2}$. Inter-row spacing was $0.75 \mathrm{~m}$ apart. Planting was done by drilling 200 seeds in each plot. All entries were planted on $12^{\text {th }}$ July, 2010. Pendametalin was applied as pre-emergence herbicide within $24 \mathrm{hrs}$ after sowing. Hoe weeding was done later as often as weeds were observed in the field. Side dressing was done using $\mathrm{P}_{2} \mathrm{O}_{5}(26 \%)$ at the rate of $30 \mathrm{Kgha}^{-1}$. Cypermethrin (a broad spectrum insecticide) was applied to the crop as often as infestation was observed in the field. Data collected were on the following parameters: number of seeds per pod, and 100 seed weight. nodule dry weight; days to $50 \%$ flowering; plant height at flowering; days to maturity; plant height at maturity; number of branches; number of pods per plant; pod weight; number of seeds / pod; number of seeds / plant; weight of 100 seeds; and yield in tons per hectare. The data was subjected to statistical analysis as described by STEEL \& TORRIE (1980).

Table 3. Analysis of variance of traits of elite Genotypes of Soybean evaluated at Yandev during the 2010 cropping season.

\begin{tabular}{|c|c|c|c|}
\hline \multirow{2}{*}{ Traits } & \multicolumn{3}{|c|}{ Meansquares } \\
\hline & Block & Entries & Error \\
\hline d.f & 2 & 19 & 38 \\
\hline NDW (g) & 1.12 & $0.15^{*}$ & 0.07 \\
\hline DF & 2.15 & $10.14 *$ & 44.32 \\
\hline $\mathrm{PHF}(\mathrm{cm})$ & 17.08 & 10.62 & 6.84 \\
\hline DM & 77.27 & $95.45^{* *}$ & 16.11 \\
\hline PHM (cm) & 59.02 & 31.72 & 20.50 \\
\hline NB & 3.99 & $0.81 *$ & 0.45 \\
\hline NPP & 2589.4 & $341.7 *$ & 156.1 \\
\hline PW (g) & 0.01 & 0.01 & 0.01 \\
\hline $\mathrm{NSP}^{1}$ & 0.00 & $0.01 * *$ & 0.00 \\
\hline $\mathrm{NSP}^{2}$ & 10729.0 & 4895.0 & 4837.0 \\
\hline WHS (g) & 1.62 & $2.85 * *$ & 0.71 \\
\hline Yld(ton ha $\left.{ }^{-1}\right)$ & 33.55 & $1.07 *$ & 0.75 \\
\hline
\end{tabular}

Abbreviations: NDW(g) - Nodule dry weight; DF - Days to 50\% flowering; PHF(cm) - Plant height at flowering; DM - Days to maturity; PHM $(\mathrm{cm})$ - Plant height at maturity; NB - Number of branches; NPP Number of pods per plant; PW(g) - Pod weight; $\mathrm{NSP}^{1}-$ Number of seeds / pod; NSP ${ }^{2}-\mathrm{Number}_{\text {of seeds / }}$ plant; WHS $(\mathrm{g})$ - Weight of 100 seeds; Yld(ton ha-1) - Yield in tons per Ha. 


\section{Results}

The analysis of variance showed that, the genotypes were statistical different for all the traits studied exception of plant height at maturity, pod weight and number of seeds per plant - Table 3. Mean yield and agronomic performance of seed yield and its component characters in soybean evaluated at Yandev is presented in Table 4. From this Table, the genotypes that have highest yields are NCRI SOY 5 (3.24 t/ha), TGX $1904-6 \mathrm{~F}(2.93 \mathrm{t} / \mathrm{ha})$ and TGX $1984-22 \mathrm{~F}(2.88 \mathrm{t} / \mathrm{ha})$. The genotypes that served as check viz. TGX $1440-1 \mathrm{E}$, TGX 1448 - 2E, TGX 1485 - 1D, TGX 1835 - 10E and TGX 923 - 2E yielded 1.36 t/ha, $1.66 \mathrm{t} / \mathrm{ha}, 1.95 \mathrm{t} / \mathrm{ha}, 1.62 \mathrm{t} / \mathrm{ha}$ and $1.4 \mathrm{t} / \mathrm{ha}$ respectively. Therefore, genotypes like NCRI SOY5 (3.24 t/ha), TGX 1904 - 6F (2.93 t/ha), TGX 1984 - 1F (2.48 t/ha) and TGX 1984 $22 \mathrm{~F}(2.88 \mathrm{t} / \mathrm{ha})$ yielded more than the checkers.

Table 4. Mean performance of seed yield and its components in Soybean evaluated at Yandev during the 2010 Season.

\begin{tabular}{|c|c|c|c|c|c|c|c|c|c|c|}
\hline Entries & $\begin{array}{l}\text { (0) } \\
\text { z } \\
\text { z }\end{array}$ & 主 & 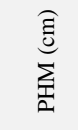 & z & 玄 & $\begin{array}{l}\text { (0) } \\
3 \\
3\end{array}$ & $\begin{array}{l}\overrightarrow{\hat{n}} \\
\text { z }\end{array}$ & $\begin{array}{l}\tilde{\tilde{n}} \\
\text { z }\end{array}$ & $\begin{array}{l}\text { क0 } \\
\text { 足 } \\
\sum_{3}^{3}\end{array}$ & 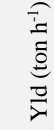 \\
\hline NCRI SOY 16 & 0.807 & 111.33 & 33.47 & 3.467 & 54.5 & 0.333 & 2.067 & 125.5 & 10.91 & 1.91 \\
\hline NCRI SOY 5 & 0.663 & 113.00 & 39.07 & 4.333 & 42.5 & 0.387 & 2.067 & 75.5 & 11.77 & 3.24 \\
\hline SAM SOY 2 & 0.700 & 114.33 & 37.90 & 4.467 & 52.5 & 0.330 & 2.000 & 73.7 & 11.05 & 1.21 \\
\hline TGX 1440-1E (check) & 0.540 & 110.33 & 31.07 & 3.867 & 36.3 & 0.333 & 2.000 & 63.3 & 10.42 & 1.36 \\
\hline TGX 1448-2E (check) & 0.503 & 112.00 & 28.73 & 3.933 & 43.2 & 0.277 & 2.000 & 93.3 & 10.50 & 1.66 \\
\hline TGX 1485-1D (check) & 0.723 & 110.33 & 28.73 & 3.000 & 39.9 & 0.377 & 2.133 & 58.5 & 9.49 & 1.95 \\
\hline TGX 1835-10E (check) & 0.843 & 96.67 & 31.80 & 3.800 & 32.2 & 0.387 & 2.067 & 63.9 & 10.87 & 1.62 \\
\hline TGX 1904-6F & 0.313 & 106.67 & 32.73 & 3.400 & 62.3 & 0.277 & 2.000 & 133.7 & 10.46 & 2.93 \\
\hline TGX 1984-17F & 0.367 & 106.33 & 34.40 & 4.267 & 47.6 & 0.417 & 2.133 & 186.5 & 8.81 & 1.68 \\
\hline TGX 1984-19F & 0.360 & 103.00 & 37.73 & 3.067 & 36.9 & 0.347 & 2.000 & 46.6 & 9.56 & 1.65 \\
\hline TGX 1984-1F & 0.323 & 112.67 & 27.87 & 3.333 & 55.1 & 0.443 & 2.000 & 117.5 & 10.18 & 2.48 \\
\hline TGX 1984-22F & 0.873 & 108.00 & 32.33 & 4.333 & 71.3 & 0.347 & 2.000 & 139.9 & 9.56 & 2.88 \\
\hline TGX 1984-5F & 0.483 & 103.00 & 31.67 & 3.733 & 48.5 & 0.390 & 2.000 & 60.5 & 9.56 & 1.77 \\
\hline TGX 1985-12F & 0.747 & 107.00 & 31.13 & 4.533 & 43.0 & 0.390 & 2.000 & 60.7 & 9.17 & 1.23 \\
\hline TGX 1986-1F & 0.983 & 108.33 & 35.60 & 4.000 & 53.0 & 0.387 & 2.000 & 80.6 & 10.64 & 1.76 \\
\hline TGX 1987-10F & 0.440 & 100.33 & 35.73 & 2.600 & 27.6 & 0.443 & 2.000 & 49.8 & 11.17 & 1.11 \\
\hline TGX 1987-19F & 0.727 & 114.00 & 33.00 & 3.80 & 52.2 & 0.387 & 2.000 & 101.5 & 9.27 & 1.91 \\
\hline TGX 1987-57F & 0.993 & 105.33 & 34.47 & 4.133 & 46.9 & 0.360 & 2.133 & 56.9 & 9.63 & 1.60 \\
\hline TGX 1987-62F & 1.007 & 103.67 & 38.40 & 3.467 & 61.3 & 0.387 & 2.000 & 53.6 & 8.81 & 1.40 \\
\hline TGX 923-2E (check) & 0.753 & 121.33 & 34.07 & 3.867 & 43.7 & 0.207 & 2.000 & 157.3 & 7.80 & 1.40 \\
\hline Lsd (5\%) & 0.452 & 6.63 & 7.48 & 1.111 & 20.6 & 0.16 & 0.105 & 114.9 & 1.39 & 1.43 \\
\hline CV & 41.6 & 3.7 & 13.5 & 17.8 & 26.3 & 26.9 & 3.1 & 77.3 & 8.5 & 47.2 \\
\hline
\end{tabular}

Key: NDW(g) - Nodule dry weight; DM - Days to maturity; PHM(cm) - Plant height at maturity; NB Number of branches; NPP - Number of pods per plant; PW(g) - Pod weight; NSP ${ }^{1}$ Number of seeds / pod; $\mathrm{NSP}^{2}-$ Number of seed / plant; WHS $(\mathrm{g})$ - Weight of 100 seeds; Yld (ton ha ${ }^{-1}$ ) - Yield in tons per Ha.

The genotypic correlation coefficient analysis for seed yield and components of soybean evaluated is presented in Table 5. This table shows that number of branches per plant, number of pods per plant, number of seeds per plant and weight of one hundred seeds were significantly correlated with seed yields. 
Table 5. Correlation coefficients of seed yield and its components in soybean evaluated at Yandev during the 2010 season

\begin{tabular}{|c|c|c|c|c|c|c|c|c|c|}
\hline Variables & $\sum^{2}$ & 吕 & $\hat{\bar{z}}$ & $\underbrace{0}_{0}$ & $\vec{z}$ & $\begin{array}{l}\overline{\bar{\sigma}} \\
\bar{Z}\end{array}$ & $\frac{\tilde{\bar{\sigma}}}{\tilde{Z}}$ & $\sum_{3}^{\infty}$ & 극 \\
\hline PHM & & $0.361^{*}$ & 0.216 & 0.209 & $0.288^{*}$ & 0.022 & 0.154 & 0.209 & 0.162 \\
\hline NB & & & $0.573 * *$ & -0.007 & $0.316^{*}$ & -0.125 & $0.407 * *$ & 0.058 & $0.323^{*}$ \\
\hline NPP & & & & 0.024 & $0.359^{*}$ & -0.129 & $0.579 * *$ & 0.089 & $0.471 * *$ \\
\hline PW (g) & & & & & -0.004 & 0.190 & 0.059 & 0.161 & 0.149 \\
\hline NDW (g) & & & & & & -0.081 & 0.106 & 0.007 & 0.059 \\
\hline NSP $^{1}$ & & & & & & & -0.130 & -0.186 & 0.058 \\
\hline NSP $^{2}$ & & & & & & & & 0.142 & $0.487 * *$ \\
\hline WHS (g) & & & & & & & & & $0.288^{*}$ \\
\hline
\end{tabular}

$*=$ significant at $5 \%, * *=$ significant $1 \%$.

Key: PHM $(\mathrm{cm})$ - Plant height at maturity; NB - Number of branches; NPP - Number of pods per plant; PW(g) - Pod weight; NDW (g) - Nodule dry weight; NSP ${ }^{1}$ - Number of seeds / pod; NSP ${ }^{2}$ - Number of seeds / plant; WHS $(\mathrm{g})$ - Weight of 100 seeds; and Yld (ton ha ${ }^{-1}$ ) - Yield in tons per hectare.

Path coefficient analysis for yield and yield component traits of soybean evaluated is presented in Table 6. Direct effects indicated in bold showed that number of seeds per plant had the highest direct effect $(0.2872)$ with yield while number of pods per plant (0.0258) had the least direct effect with yield. Figure 1 revealed the path diagram for yield and yield components of soybean evaluated at Yandev during the 2010 season. The doublearrowed lines indicate the genotypic correlation between traits while the single- arrowed lines indicate the path coefficients (direct effect).

Table 6. Direct (bold) effect of seed yield and its component characters in soybean evaluated at Yandev during the 2010season.

\begin{tabular}{lccccc}
\hline \multicolumn{1}{c}{ Variables } & NB & NPP & NSP2 & WHS & YLD \\
\hline NB & $\mathbf{0 . 0 4 5 0}$ & 0.1482 & 0.0116 & 0.0129 & 0.323 \\
NPP & 0.0258 & $\mathbf{0 . 0 2 5 8}$ & 0.1664 & 0.0198 & 0.4708 \\
NSP $^{2}$ & 0.0184 & 0.1499 & $\mathbf{0 . 2 8 7 2}$ & 0.0314 & 0.487 \\
WHS & 0.0026 & 0.0231 & 0.0407 & $\mathbf{0 . 2 2 1 0}$ & 0.288 \\
\hline
\end{tabular}

$*=$ significant at $5 \%, * *=$ significant $1 \%$.

Key: NB - Number of branches; NPP - Number of pods per plant; NSP ${ }^{2}-$ Number of seeds/ plant; WHS(g) Weight of 100 seeds; YLD (ton ha ${ }^{-1}$ ) - Yield in tons per hectare.

The stepwise regression analysis of the contribution of some agronomic characters to seed yield at Yandev is presented in Table 7. The regression of yield on number of pods per plant and weight $(\mathrm{g})$ of one hundred seeds were significant while the regression of other yield components under study were not significant. The proportion of the variability that existed in the soybean when only number of pods per plant was involved in the yield equation was $48 \%$. That of weight $(\mathrm{g})$ of one hundred seeds was $6 \%$. 
Table 7. Regression of seed yield and its components in soybean evaluated at Yandev during the 2010 season.

\begin{tabular}{cccccccc}
\hline Model & Variables & $\begin{array}{c}\text { Coefficient of } \\
\text { variation }\end{array}$ & $\mathbf{R}^{2}$ & $\begin{array}{c}\mathbf{R}^{2} \\
\text { change }\end{array}$ & $\begin{array}{c}\text { Proportion due } \\
\text { to regression }\end{array}$ & $\begin{array}{c}\text { Cumulative } \\
\text { regression }\end{array}$ & Significance \\
\hline $\mathbf{1}$ & NPP & $0.482^{\mathrm{a}}$ & 0.232 & 0.219 & $48 \%$ & $48 \%$ & 0.05 \\
$\mathbf{2}$ & WHS (g) & $0.542^{\mathrm{b}}$ & 0.293 & 0.269 & $6 \%$ & $54 \%$ & 0.05 \\
\hline \multicolumn{2}{l}{ Where: Predictors: (Constant), NPP; Predictors: (Constant), NPP, WHS (g); Dependent variable: Yld (t/ha) } \\
\hline
\end{tabular}

\section{Discussions}

The highly significant and significant variability exhibited in the twelve characters of soybean as revealed by analysis of variance showed that the genotypes are diverse. Such variations are useful in plant breeding as they provide heterogeneous population for a wide spectrum of genotypes for selection for the characters. These results agreed with the findings of GHATGE \& KADU (1993) and RASAILY \& al. (1986), SHAAHU \& al. (2012, 2014) who obtained considerable genotypic variability for seed yield.

The results of the correlation coefficient analysis revealed that seed yield had highly significant positive correlation with number of pods per plant and number of seeds per plant. Similarly, seed yield had significant positive correlation with number of branches per plant and weight of one hundred seeds. Number of branches per plant had positive and highly significant correlation with the number of pods per plant and number of seeds per plant. Many researchers: NAKAWUKA \& al. (1999), IQBAL \& al. (2003) and MALIK \& ADIPALA (2006) also found highly significant genotypic correlation coefficient of seed yield with number of pods per plant. MALIK \& al. (2007), TAYYAR (2007), COPUR \& al. (2009) and SHAAHU\& al. $(2012,2014)$ showed that the seed yield was positively and significantly correlated with pod number, fruit branch and 1000-seed weight. These results are in agreement with other reports by AKTHER \& SNELLER (1996) and BOARD \& al. (1997) who found strong positive correlations between seed yield with pods per plant and seeds per plant.

The results of the path analysis indicated that the direct effect of number of branches per plant, number of pods per plant, number of seeds per plant and weight (g) of one hundred seeds. This confirms the results of KHAN \& al. (2000); SINGH \& YADAVA (2000) who reported that 100-seed weight, branches per plant, number of pods per plant and number of seeds per plant had direct effects on seed yield in soybean. This shows that selecting for these characters may lead to increase in seed yield.

The coefficient of determination $\left(\mathrm{R}^{2}\right)$ explains the amount of variability in yield due to number of pods per plant and weight of one hundred seeds. The F-test revealed a highly significant regression value for all levels of combination of the yield components as well as their combination have significant effects on yield. The F-test showed that only number of pods per plant and weight of one hundred seeds are statistically significant (regression coefficient of 0.48 and 0.06 respectively). This seems to indicate that only number of pods per plant and weight of one hundred seeds currently influence yield. The proportion due to regression for number of pods per plant on seed yield was $48 \%$ and that of weight of one hundred seeds was $6 \%$.

The results of the experiment seem to suggest that, in breeding, the traits to consider for when breeding pods per plant, seeds per plant and weight of one hundred 
seeds. Moreover, it may be recommended that more research should be conducted using the population in this experiment so as to get a more stable results over location and year.

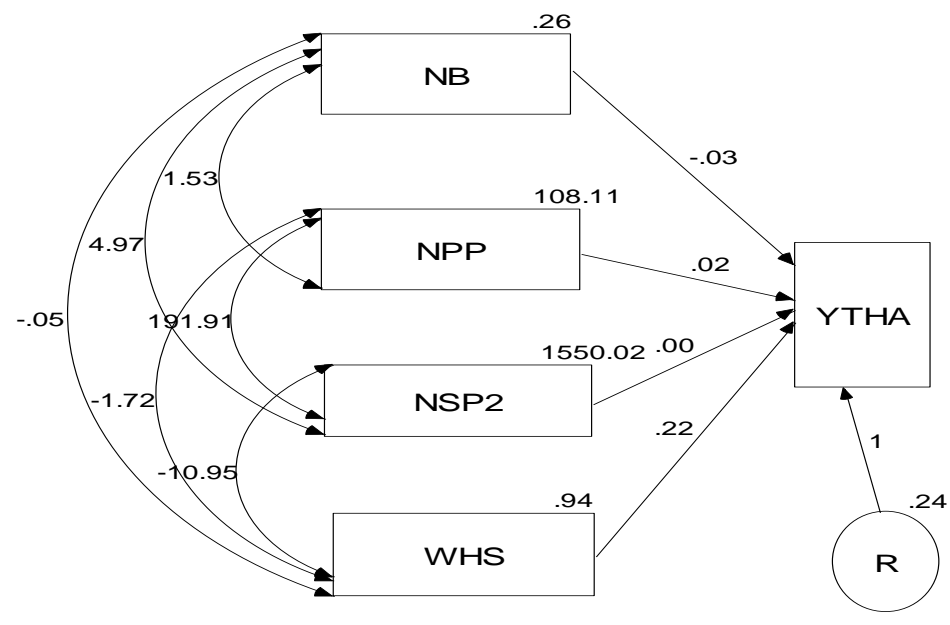

Figure 1. Path diagram for yield and yield components of soybean evaluated at Yandev during the 2010 season. [Key: Double-arrowed lines indicate the genotypic correlation between traits. Singlearrowed lines indicate the path coefficients (direct effect). NB - number of branches per plant; NPP Number of pods per plant; NSP2 - Number of seeds per plant; WHS - Weight of one hundred seeds; YTHA - Yield in tons per hectare; and R - Error].

\section{Conclusions}

The analysis of variance showed significant in difference in nodule dry weight; days to $50 \%$ flowering; days to maturity; plant height at maturity; number of branches; number of pods per plant; number of seeds/ plant; and weight of 100 seeds among the genotypes studied. The result of this experiment conducted showed that there were highly significant correlation on number of pods per plant, number of seeds per plant, and significant correlation of one hundred seed with seed yield. The results of the path coefficient analysis also showed that number of pods per plant exerted the highest direct effect on seed yield. Weight (g) of one hundred seeds showed the least direct effect among the traits evaluated. The regression on seed yield and its component character also showed that number of pods per plant had the highest contribution to seed yield with the proportion due to regression being $48 \%$. The relative contribution of number of branches per plant to seed yield was $2 \%$.

\section{Notes on contributors}

Gabriel Ojonimi. ABIMAJE - is a plant breeder with special interest in soybean breeding. Terkimbi VANGE - is a plant breeder and biometrician. His work focuses on rice and soybean breeding and data analysis. Daniel Kparafa ADEDZWA - is a plant breeder with special interest in soybean breeding. Aondover SHAAHU - is a plant breeder with special interest in soybean breeding. 


\section{References}

AKANDE S. R., OWOLADE O. F. \& AYANWALE J. A. 2007. Field evaluation of soybean varieties at Ilorin in Southern Guinea Savanna ecology of Nigeria. Afr. J. Agric. Res. 2: 356-358.

AKTHER M. \& SNELLER C. H. 1996. Yield and yield components of early maturing Soybean genotypes in the mid-South. Journal of Crop science. 36: 877-882.

ALGHAMDI S. S. 2004. Yield stability of some soybean genotypes across diverse environments. Pak. J. Biol. Sci. 7: 2109-2114. http://dx.doi.org/10.3923/pjbs.2004.2109-2114.

BOARD J. E., KANG M. S. \& HARVILLE B. G. 1997. Path analysis identity in direct selection criteria for yield of late-planted soybean. Crop Science. 37: 879-884.

COPOUR O., GUR M. A., DEMIREL U. \& KARAKUS M. 2009. Performance of some soybean [Glycine max (L.) Merr.] genotypes double cropped in semi-arid conditions. Not. Bot. Hort. Agrobot. Cluj. 37(2): 8591. DOI: http://dx.doi.org/10.15835/nbha3723260.

ENCARTA. 2008. Encarta premium Suits Encyclopedia. Microsoft Corporation. Seattle, USA.

GHATGE R. D. \& KADU R. N. 1993. Genetic variability and heritability studies in soybean. Advances Pl. Sci. 6: 224-228.

GRAFIUS J. E. 1959. Heterosis in Barley. Journal of Agronomy. 51: 515-518.

IQBAL S., MAHMOOD T., TAHIRA M., ALI M., ANWAR M. \& SARWAR M. 2003. Path coefficient analysis in different genotypes of soybean (Glycine max (L.) Merril). Pakistan Journal of Biological Sciences. 6: 1085-1087.

KHAN A., HATAM M. \& KHAN A. 2000. Heritability and interrelationship among yield determining components of soybean varieties. Pak. Journal of Agricultural Research. 116: 5-8.

MALIK M. F. A., ASHRAF M., QURESHI A. S. \& GHAFOOR A. 2007. Assessment of genetic variability, correlation and path analyses for yield and its components in soybean. Pakistan Journal of Botany. 39(2): 405-413.

MALIK M. F. A., QURESHI A. S., ASHRAF M. \& GHAFOOR A. 2006. Genetic variability of the of the main yield related characters in soybean. International Journal of Agriculture and Biology. 8(6): 815-819.

NAKAWUKA C. K. \& ADIPALA E. 1999. A path coefficient analysis of some yield component interactions in cowpea. African Crop Science Journal. 7: 327-331.

RASAILY S. K., DESAI N. D. \& KUKADJA M. U. 1986. Genetic variability in soybean. (Glycine max (L.) Merrill). Gujrat Agricultural University Research Journal. 11: 57-60.

SHAAHU A., BELLO L. L. \& VANGE T. 2014. Field Evaluation of Some Soybean (Glycine max (L.) Merrill) Genotypes at Makurdi in the Southern Guinea Savannah Ecology of Nigeria. International Journal of Applied Research and Technology. 3(5): 64-69.

SHAAHU A., VANGE T. \& BELLO L. L. 2012. Genetic evaluation of some newly developed soybean genotypes (Glycine max) in Benue State of Nigeria. Indian Journal of Agricultural Sciences. 82(7): 578-581.

SINGH J. \& YADAVA H. S. 2000. Factors determining seed yield in early generation of soybean. Crop Res. Hisar. 20: $239-243$.

SINGH P., KUMAR R., SABAPATHY S. N. \& BAWA A. S. 2008.Functional and edible uses of soyprotein products. Reviews in Food Science and Food Safety. 7: 14-28.

STEEL R. G. D. \& TORRIE J. S. 1984. Principals and Procedures of Statistics: A biometrical Approach, McGraw Hill Book correlated. Inc., New York (USA).

TAYYAR S. 2007. Performance of some soybean (Glycine max (L.) Merrill) genotypes as main crop in Biga conditions. Journal of Agricultural Science. 17(2): 55-59.

TOlEDO J. F. F. de ARIAS C. A. A., OliVEIRA M. F., de TRILlER C. \& MIRANDA Z. de F. S. 2000. Genetical and environmental analyses of yield in six biparental soybean crosses. Pesq. agropec. bras., Brasilia. 35: 1783-1796. http://dx.doi.org/10.1590/S0100-204X2000000900011.

\section{How to cite this article:}

ABIMAJE G. O., VANGE T., ADEDZWA D. K. \& SHAAHU A. 2018. Studies on the interrelationship between yield and agronomic traits in some selected soybean lines at Yandev in Southern Guinea Savannah of Nigeria. J. Plant Develop. 25: 77-84. https://doi.org/10.33628/jpd.2018.25.1.77 